\title{
Comparison between the $1 \%$ and $2 \%$ ibopamine provocative test in primary open-angle glaucoma patients: sensitivity, specificity and tolerability
}

\author{
Comparação entre o teste de ibopamina a $1 \%$ e a $2 \%$ no glaucoma primá rio \\ dêanguloaberto: sensibilidade, especificidade e tolerabilidade
}

\author{
Leopoldo Magacho ${ }^{1}$ \\ Marcelus Layguel Costa ${ }^{2}$ \\ André Dessimoni ${ }^{3}$ \\ Marcos Pereira de Ávila ${ }^{4}$
}

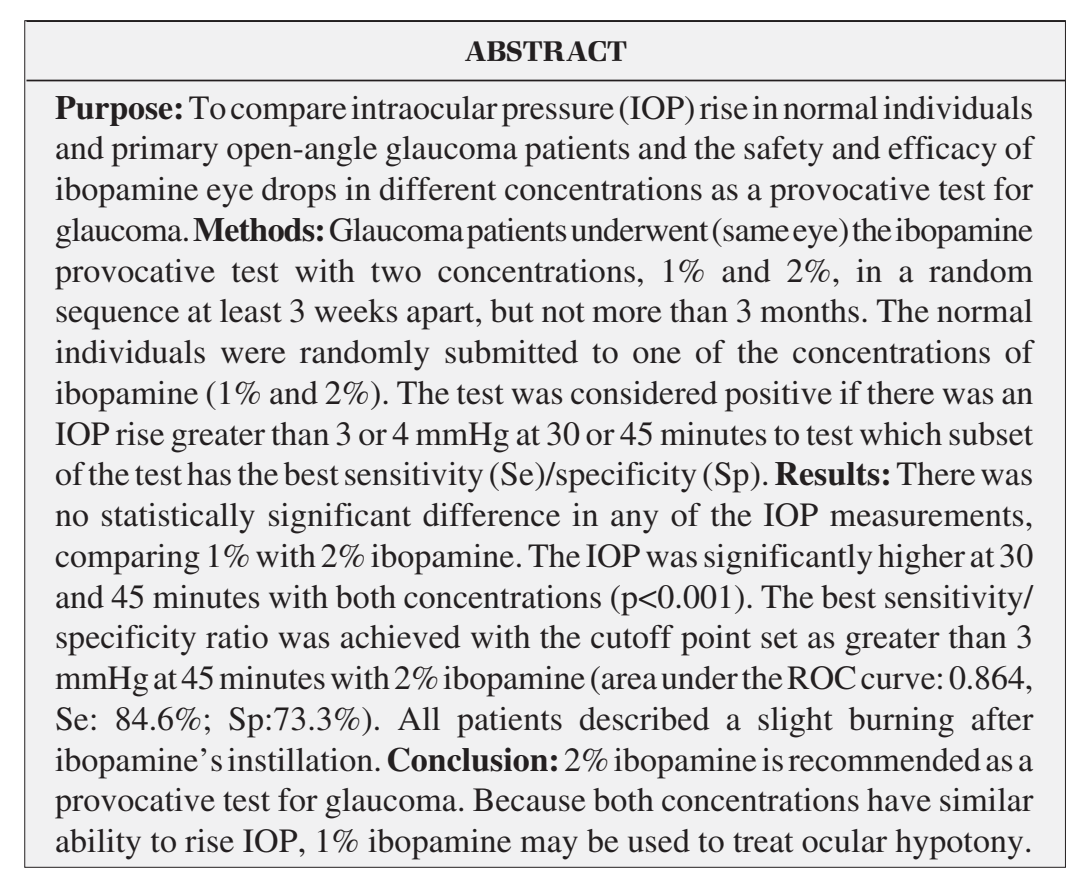

Keywords: Dopamine Agonists/administration \& dosage; Glaucoma, open-angle/diagnosis; Intraocular pressure/drug effects; Ophthalmic solutions; Sensitivity and specificity

\footnotetext{
Trabalho realizado no Setor de Glaucoma do Centro de Referência em Oftalmologia da Universidade Federal de Goiás - UFG - Goiânia (GO) - Brasil.

Doutor em Oftalmologia pela Universidade Estadual de Campinas - UNICAMP - Campinas (SP) - Brasil.

Assistente do Setor de Glaucoma do Centro de Referência em Oftalmologia da UFG - Goiânia (GO) - Brasil. Oftalmologista do Setor de Glaucoma do Centro de Referência em Oftalmologia da UFG - Goiânia (GO) Brasil.

${ }^{4}$ Professor Doutor e Chefe do Centro de Referência em Oftalmologia da UFG - Goiânia (GO) - Brasil.

Endereço para correspondência: Leopoldo Magacho. Rua 131, nº 313 - Setor Sul - Goiânia (GO) CEP 74093-200 E-mail: lmagacho@brturbo.com.br

Recebido para publicação em 04.04.2005

Última versão recebida em 27.12.2005

Aprovação em 05.01.2006

Os autores não possuem interesse comercial sobre qualquer produto citado no texto.
}

\section{INTRODUCTION}

Several provocative tests have been designed to establish predictive factors for glaucoma ${ }^{(1-3)}$. However, none of them have proved to be of clinical value.

Ibopamine ( $\mathrm{N}$-methyldopamine 3,4 diisobutyric ester) eye drops are hydrolyzed to epinine, an analogue of dopamine. Epinine binds to $\alpha$-adrenergic and D-1 dopaminergic receptors. The adrenergic binding causes a non-cycloplegic mydriasis, while the D-1 dopaminergic action causes an increase in aqueous humor production ${ }^{(4-8)}$. Because it increases aqueous humour production, ibopamine eyedrops have been successfully used to treat post-trabeculectomy hypotony ${ }^{(9-10)}$. Since many glaucomas may have an impaired outflow system, glaucoma subjects usually have a greater rise in intraocular pressure compared to normal subjects ${ }^{(7,11-14)}$.

However, despite presumable minor systemic effects of ibopamine eye 
696 Comparison between the 1\% and 2\% ibopamine provocative test in primary open-angle glaucoma patients:

sensitivity, specificity and tolerability

drops when used as a provocative test (only 2 drops), ibopamine is a dopaminergic analogue used in cardiac diseases with some described adverse effects ${ }^{(15-17)}$. Patients using ibopamine to treat ocular hypotony would be at greater risk of adverse events, since they would be using ibopamine eyedrops 3 to 4 times/day ${ }^{(10)}$. Thus, ibopamine eye drops with lower concentration and similar efficacy are desirable.

All studies with ibopamine as a provocative test for glaucoma have used the $2 \%$ eye drops ${ }^{(7,11-14)}$. However, the ibopamine is also commercially available at $1 \%$. The purpose of this study is to compare intraocular pressure (IOP) rise in normal individuals and in primary open-angle glaucoma patients and the safety and efficacy of the ibopamine eye drops in different concentrations as a provocative test for glaucoma.

\section{METHODS}

This is a prospective comparative study including glaucoma patients from the Federal University of Goiás, Glaucoma Service. Normal subjects were recruited from volunteers of the medical staff, university members, family and friends of patients. Only one eye per subject was randomly selected if both were eligible. An informed and written consent was obtained for both groups. This study followed the tenets of the Declaration of Helsinki and was approved by the Ethics Committee of the Federal University of Goiás.

The inclusion criteria for the glaucomatous group were: primary open-angle glaucoma: $\mathrm{IOP} \geq 21 \mathrm{mmHg}$ at least on two occasions, as measured by a calibrated Goldmann tonometer; gonioscopy showing an open angle; typical optic disc neuropathy, that is, localized or generalized narrowing of the neuroretinal rim, disc hemorrhage, or cup/disc asymmetry $>0.2$ and at least two reliable and recent (at least 6 months) SITA Standard Humphrey 24-2 abnormal visual fields ${ }^{(18)}$.

Normal subjects were included after a comprehensive ophthalmic examination, including Goldmann applanation tonometry (IOP $<21 \mathrm{mmHg}$ ), an absence of glaucomatous optic disc (as described above), gonioscopy showing an open angle and a normal and reliable SITA Standard 24-2 perimetric examination ${ }^{(18)}$.

Exclusion criteria included narrow angles, secondary glaucoma, ocular hypertension (IOP > $21 \mathrm{mmHg}$ with normal optic disc and perimetric examination), glaucoma suspects (based on the optic disc, but with IOP $<21 \mathrm{mmHg}$ and no corresponding field damage) or any significant change on slit lamp examination that could interfere with the perimetric examination (i.e: macular degeneration) or with the tonometry (i.e: corneal scars). We also excluded patients who underwent refractive surgery, using prostaglandin analogues ${ }^{(11)}$, recent history (6 months) of ocular inflammation, functional anti-glaucomatous surgery (trabeculectomy, tube shunts), inability to perform any of the examinations or refusal to participate in the study.

The eligible glaucoma patients were submitted (same eye) to the ibopamine provocative test at 2 concentrations, $1 \%$ and $2 \%$, in a random sequence at least 3 weeks apart, but not more than 3 months. The normal individuals were randomly submitted to one of the concentrations of the ibopamine (1\% or $2 \%)$. All participants followed a standardized sequence: baseline IOP measurement around 9:00 o'clock AM, instillation of 2 ibopamine eyedrops, 5 minutes apart, followed by IOP measurement 30 and 45 minutes after the second drop. Mydriasis was considered as total $(>6 \mathrm{~mm})$ or not $(<6 \mathrm{~mm})$ in all patients as measured by a horizontal slit in the biomicroscopy examination.

The IOP considered was the mean of two consecutive measurements, always using the same calibrated tonometer by the same masked examiner (a second person read the IOP). If the difference between the first and the second measurements was greater than $2 \mathrm{mmHg}$, a third measurement was made, with the most discrepant value discarded.

Statistical analysis was done with the SPSS software (SPSS Inc, Chicago, IL,), version 11.5. The Komogorov-Smirnov test was used to test the normality of our distribution. The paired $t$ test was used to compare the IOP before and after ibopamine instillation in both concentrations, and between them. The IOP in the normal individuals was compared with the independent student's t test. Considering the alpha error as 0.05 , power of $80 \%$, standard deviation within groups as 1 , and the difference of means to be detected as 1 , the necessary sample size to detect significant differences between groups was set as 10 for the paired tests and 17 for the unpaired comparison. The ibopamine test was considered positive when the IOP increase exceeded 3 (cutoff number 1) or $4 \mathrm{mmHg}$ (cutoff number 2) at 30 minutes (timepoint number 1) or 45 minutes (timepoint number 2) sensitivity and specificity of the test were calculated for each subset of the test and ROC curves created to find the best area under the curve and cutoff point in the diagnosis of glaucoma for each ibopamine concentration at 30 and 45 minutes. Any systemic adverse event noticed by the patients was considered as ibopamine's side effect.

\section{RESULTS}

Thirteen glaucoma patients were included (two women). The mean age was 64.3 \pm 9.7 years old. The mean Mean Deviation (MD) was $-5.1 \pm 1.7 \mathrm{~dB}$ (from $-2.59 \mathrm{~dB}$ to $-9.33 \mathrm{~dB}$ ), and the mean Pattern Standard Deviation was $5.2 \pm 2.1 \mathrm{~dB}$ (from 1.74 to $8.50)$. In the normal group, 15 subjects were submitted to $2 \%$ ibopamine test (mean age: $51.8 \pm 14.4$ years old, 11 women and 2 men) and in 13 individuals $1 \%$ ibopamine was instilled (mean age: $55.1 \pm 8.5$ years old, $\mathrm{p}=0.4 ; 7$ women and 6 men). Complete mydriasis $(>6 \mathrm{~mm}$ ) was achieved in all individuals with both concentrations.

IOP distribution in the glaucoma group is illustrated in table 1 . There was no statistically significant difference in any of the measurements, comparing the ibopamine test at $1 \%$ with ibopamine test at $2 \%$ (Table 1 ). The IOP was significantly higher at 30 and 45 minutes with both concentrations ( $\mathrm{p}<0.001$ for all tests). IOP in 
the normal individuals is shown in table 2. IOP was significantly higher in the normal individuals at 30 minutes ( $\mathrm{p}=0.003$ with $2 \%$ ibopamine and $\mathrm{p}=0.001$ with $1 \%$ ibopamine) and at 45 minutes with $2 \%$ ibopamine $(\mathrm{p}=0.007)$. IOP rise was borderline with $1 \%$ ibopamine at 45 minutes $(\mathrm{p}=0.05)$.

The sensitivity and specificity for all analyzed cutoffs and timepoints are displayed in table 3. The area under the ROC curve was 0.781 (95\% confidence interval, CI: $0.598 ; 0.964)$ and 0.861 (95\% CI: $0.717 ; 1.004$ ) (Figure 1) for the $1 \%$ Ibopamine provocative test at 30 and 45 minutes, respectively. The $2 \%$ ibopamine provocative test achieved an area under the ROC curve of 0.736 (95\% CI: $0.544 ; 0.928)$ at 30 minutes and an area under the ROC curve of 0.864 (95\% CI: $0.722 ; 1.006)$ at 45 minutes (Figure 2). The best cutoff (IOP rise) in all timepoints for all ibopamine concentrations was greater than $3 \mathrm{mmHg}$. No subjective systemic effect was noticed in the whole study. All patients described a slight burning after ibopamine's instillation.

\begin{tabular}{|c|c|c|c|}
\hline \multirow[b]{2}{*}{$\begin{array}{l}\text { table } 2 \text {. IOP was significantly } \\
30 \text { minutes ( } \mathrm{p}=0.003 \text { with } 2 \% \\
\text { bopamine) and at } 45 \text { minutes } \\
\text { rise was borderline with } 1 \% \\
\text { for all analyzed cutoffs and } \\
\text { 3. The area under the ROC } \\
\text { nterval, CI: } 0.598 ; 0.964 \text { ) and } \\
\text { zure } 1 \text { ) for the } 1 \% \text { Ibopamine } \\
\text { nutes, respectively. The } 2 \% \\
\text { ved an area under the ROC } \\
28 \text { ) at } 30 \text { minutes and an area } \\
95 \% \text { CI: } 0.722 ; 1.006 \text { ) at } 45 \\
\text { (IOP rise) in all timepoints for } \\
\text { reater than } 3 \text { mmHg. No sub- } \\
\text { d in the whole study. All pa- } \\
\text { ter ibopamine's instillation. }\end{array}$} & \multicolumn{3}{|c|}{ DISCUSSION } \\
\hline & \multicolumn{3}{|c|}{$\begin{array}{l}\text { In developed countries, fewer than } 50 \% \text { of those with } \\
\text { glaucoma are aware of their disease. In the developing world, } \\
\text { the rate of known disease is even lower }{ }^{(19)} \text {. Screening metho- } \\
\text { ds for glaucoma, including an accurate and easy to perform } \\
\text { provocative test would decrease the number of impaired peo- } \\
\text { ple due to glaucoma and also reduce the direct and indirect } \\
\text { costs of the disease }{ }^{(20)} \text {. } \\
\text { Ibopamine has been used as a provocative test for glauco- } \\
\text { ma in the past few years with good sensitivity and specificity in } \\
\text { the diagnosis of glaucoma }{ }^{(11-12,14)} \text {. Additionally, excluding the } \\
\text { prostaglandin analogues, the use of anti-glaucomatous drugs } \\
\text { do not alter the test's performance }{ }^{(11)} \text {. Thus, we only eliminated } \\
\text { from our analysis patients using this class of drugs. } \\
\text { The glaucomatous population had, as an average, initial } \\
\text { visual field damage (MD: }-5.1 \pm 1.7 \mathrm{~dB} \text { ). In a screening program, }\end{array}$} \\
\hline Test & Mean & Standard deviation & $p^{*}$ \\
\hline $2 \%$ ibopamine & 18.07 & 4.34 & 1.00 \\
\hline $1 \%$ ibopamine & 18.07 & 2.21 & \\
\hline $2 \%$ ibopamine & 22.38 & 4.36 & 0.8 \\
\hline $1 \%$ ibopamine & 22.23 & 3.32 & \\
\hline $2 \%$ ibopamine & 23.76 & 3.85 & 0.3 \\
\hline $1 \%$ ibopamine & 23.00 & 3.55 & \\
\hline $2 \%$ ibopamine & 4.30 & 3.03 & 0.8 \\
\hline $1 \%$ ibopamine & 4.15 & 2.30 & \\
\hline $2 \%$ ibopamine & 5.69 & 2.75 & 0.3 \\
\hline $1 \%$ ibopamine & 4.92 & 2.49 & \\
\hline
\end{tabular}

\begin{tabular}{|c|c|c|c|c|}
\hline Intraocular pressure $(\mathrm{mmHg})$ & Test & Mean & Standard deviation & $\mathbf{p}^{*}$ \\
\hline \multirow[t]{2}{*}{ Baseline } & $2 \%$ ibopamine & 15.46 & 2.06 & 0.2 \\
\hline & $1 \%$ ibopamine & 14.00 & 3.35 & \\
\hline \multirow[t]{2}{*}{ After 30 minutes } & $2 \%$ ibopamine & 17.38 & 2.21 & 0.2 \\
\hline & $1 \%$ ibopamine & 15.86 & 4.24 & \\
\hline \multirow[t]{2}{*}{ After 45 minutes } & $2 \%$ ibopamine & 16.61 & 2.66 & 0.5 \\
\hline & $1 \%$ ibopamine & 15.66 & 4.46 & \\
\hline \multirow[t]{2}{*}{ IOP rise after 30 minutes } & $2 \%$ ibopamine & 1.92 & 1.65 & 0.9 \\
\hline & $1 \%$ ibopamine & 1.86 & 2.03 & \\
\hline \multirow[t]{2}{*}{ IOP rise after 45 minutes } & $2 \%$ ibopamine & 1.15 & 1.95 & 0.5 \\
\hline & $1 \%$ ibopamine & 1.66 & 2.02 & \\
\hline
\end{tabular}

\begin{tabular}{|c|c|c|c|c|c|}
\hline \multirow[t]{2}{*}{ Timepoint } & \multirow[t]{2}{*}{ Cutoff } & \multicolumn{2}{|c|}{$1 \%$ Ibopamine } & \multicolumn{2}{|c|}{$2 \%$ lbopamine } \\
\hline & & Sensitivity & Specificity & Sensitivity & Specificity \\
\hline \multirow[t]{2}{*}{ After 30 minutes } & $>3 \mathrm{mmHg}$ & $61.5 \%$ & $84.6 \%$ & $69.2 \%$ & $73.3 \%$ \\
\hline & $>4 \mathrm{mmHg}$ & $46.1 \%$ & $92.3 \%$ & $38.4 \%$ & $93.3 \%$ \\
\hline \multirow[t]{2}{*}{ After 45 minutes } & $>3 \mathrm{mmHg}$ & $69.2 \%$ & $100.0 \%$ & $84.6 \%$ & $73.3 \%$ \\
\hline & $>4 \mathrm{mmHg}$ & $61.5 \%$ & $100.0 \%$ & $61.5 \%$ & $86.6 \%$ \\
\hline
\end{tabular}




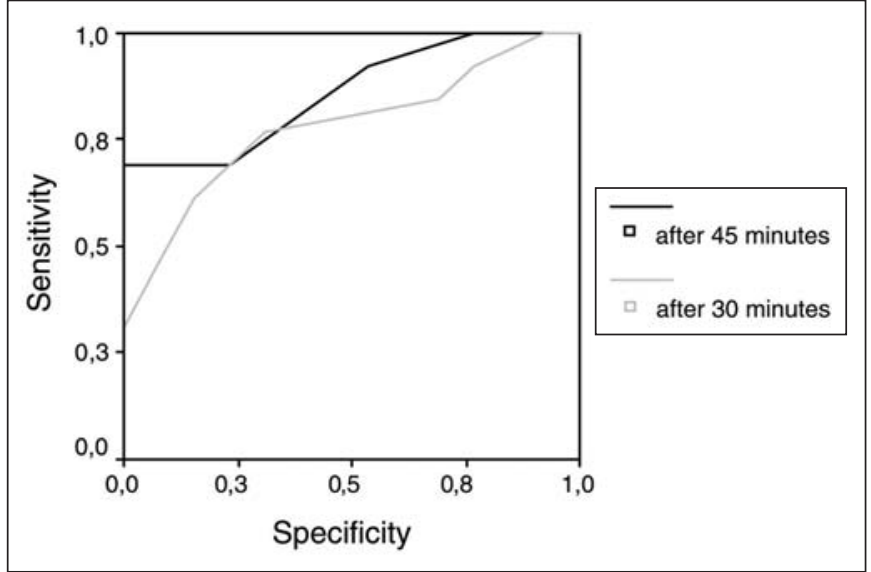

Figure 1 - ROC curves for the $1 \%$ ibopamine provocative test

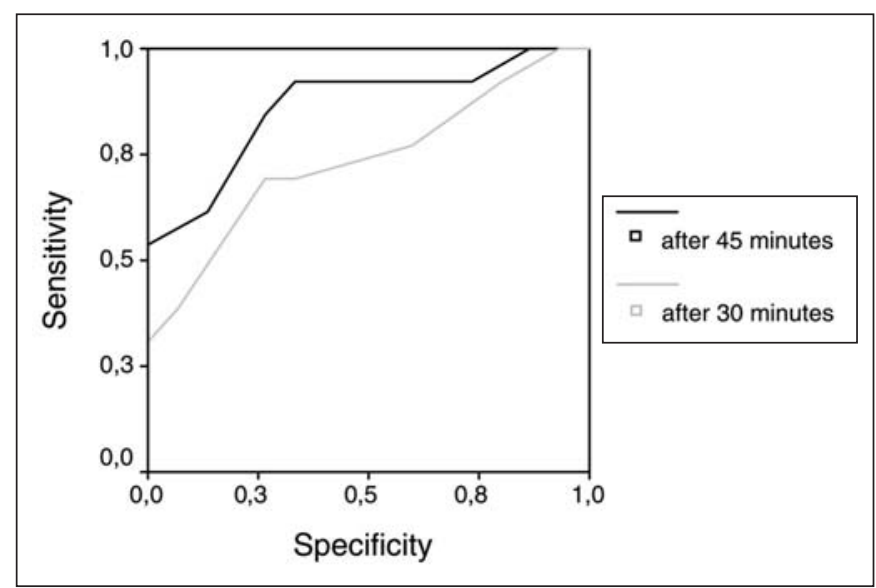

Figure 2 - ROC curves for the $2 \%$ ibopamine provocative test

suggested the best sensitivity/specificity ratio with $1 \%$ ibopamine at 45 minutes (area under the ROC curve: 0.861, Figure 1), similar to the $2 \%$ ibopamine at the same timepoint, especially due to a high specificity $(100 \%)$, with reasonable sensitivity (69.2\%) with ibopamine at the lower concentrations. However, the ideal for a provocative test for glaucoma would be an easy protocol with high sensitivity (to diagnose people that really have glaucoma), but with acceptable specificity (not to treat normal individuals as glaucoma patients). Moreover, after a screening process, follow-up visits may rule out normal individuals, but we could miss the chance to diagnose and treat a new glaucoma case. In this way, we believe the $2 \%$ ibopamine should be the choice for a provocative test for glaucoma, with a cutoff point set greater than $3 \mathrm{mmHg}$ at 45 minutes in order to achieve the best sensitivity $(84.6 \%)$ and acceptable specificity $(73.3 \%)$. Furthermore, in a recent study, we have found that the $2 \%$ ibopamine provocative test was correlated with the IOP peak in the diurnal tension curve, better at 45 minutes than at 30 minutes (unpublished data).

On the other hand, both ibopamine concentrations have reliably increased IOP in normal individuals and glaucoma patients, with no noticeable difference between the concentrations (Tables 1 and 2). Consequently, it is possible to use $1 \%$ ibopamine to treat post-surgery ${ }^{(9,10)}$ or post-uveitis ${ }^{(22)}$ ocular hypotony with the same efficacy of $2 \%$ ibopamine. Despite no adverse effect in the study, all individuals received a small dose (2 drops). However, the probability of adverse systemic events with the chronic use of ibopamine, such as long-term hypertension, is higher, and demands its use in lower concentrations.

\section{CONCLUSION}

The ibopamine provocative test is safe and has good sensitivity and specificity, with both concentrations of the drug (1\% and $2 \%$ ). However, due to a higher sensitivity, the $2 \%$ Ibopamine is recommended. Because both concentrations have similar ability to raise the IOP, $1 \%$ ibopamine may be used to treat ocular hypotony. 


\section{RESUMO}

Objetivo: Comparar a tolerabilidade e a eficácia do teste provocativo da ibopamina com diferentes concentrações em pacientes com glaucoma primário de ângulo aberto. Métodos: Pacientes com glaucoma (mesmo olho) foram aleatoriamente submetidos ao teste provocativo da ibopamina com as duas concentrações comercialmente disponíveis: $1 \%$ e $2 \%$ com pelo menos 3 semanas de intervalo, mas não superior a 3 meses. Os indivíduos normais foram randomizados a uma das concentrações utilizadas. O teste era considerado positivo se houvesse elevação da pressão intra-ocular (Pio) superior a 3 ou $4 \mathrm{mmHg} 30$ ou 45 minutos após o início do teste para se estabelecer a melhor relação sensibilidade (Se)/especificidade (Es) do teste. Resultados: Treze pacientes com glaucoma, 15 indivíduos normais com a ibopamina a $2 \%$ e 13 com a ibopamina a $1 \%$ foram incluídos. Não houve diferença estatisticamente significativa em qualquer uma das médias da Pio entre a ibopamina a $1 \%$ ou a $2 \%$. A Pio foi significativamente maior aos 30 e 45 minutos com ambas as concentrações $(\mathrm{p}<0,001)$. A melhor relação Se/Es foi obtida com o aumento da Pio $>3 \mathrm{mmHg}, 45$ minutos após o teste com a ibopamina a 2\% (área abaixo da curva ROC: 0,864, Se: 84,6\%; Es: $73,3 \%$ ). Todos os pacientes referiram leve ardência à instilação da ibopamina. Conclusão: Sugere-se a utilização da ibopamina a $2 \%$ como teste provocativo para o glaucoma. Como ambas as concentrações apresentaram capacidade similar em elevar a Pio, a Ibopamina a $1 \%$ (menor concentração da droga) pode ser utilizada por períodos prolongados, como na hipotonia ocular.

Descritores: Agonistas dopaminérgicos/administração \& dosagem; Glaucoma de ângulo aberto/diagnóstico; Pressão intraocular/efeito de drogas; Soluções oftálmicas. Tolerância e eficácia; Sensibilidade e especificidade

\section{REFERENCES}

\footnotetext{
1. Armaly, MF. Water-drinking test. I. Characteristics of the ocular pressure res-
} ponse and the effect of age. Arch Ophthalmol. 1970;83(2):169-75.
2. Spaeth GL. Effects of topical dexamethasone on intraocular pressure and the water drinking test. Arch Ophthalmol. 1966;76(6):772-83.

3. Harris LS, Galin MA. Cycloplegic provocative testing. Arch Ophthalmol. 1969;81(3):356-8.

4. Marchini G, Babighian S, Tosi R, Perfetti S, Bonomi L. Effects of 2\% ibopamine on pupil, refraction, anterior segment anatomy and intraocular pressure. J Ocul Pharmacol Ther. 2001;17(3):215-23.

5. Marchini G, Babighian S, Tosi R, Perfetti S, Bonomi L. Comparative study of the effects of $2 \%$ ibopamine, $10 \%$ phenylephrine, and $1 \%$ tropicamide on the anterior segment. Invest Ophthalmol Vis Sci. 2003;44(1):281-9.

6. Virno, M, Taverniti, L, Pecori Giraldi, J. Ibopamina: nuevo midriatico non cicloplegico (nota preliminare). Boll Ocul. 1986;65:1135-46.

7. Virno M, Taverniti L, De Gregorio F, Sedran L, Longo F. Increase in aqueous humor production following D1 receptors activation by means of ibopamine. Int Ophthalmol. 1996-97;20(1-3):141-6.

8. McLaren JW, Herman DC, Brubaker RF, Nau CB, Wayman LL, Ciarniello $\mathrm{MG}$, et al. Effect of ibopamine on aqueous humor production in normotensive humans. Invest Ophthalmol Vis Sci. 2003;44(11):4853-8.

9. Virno M, De Gregorio F, Pannarale L, Arrico L. Topical ibopamine and corticosteroids in the treatment of post-surgery ocular hypotony. Int Ophthalmol. 1996-97;20(1-3):147-50.

10. Di Giulio, S, De Stefano, C, Boccassini, B, Boccassini, G. Post-trabeculectomy hypotension and hypoathalamia: efficacy of treatment with ibopamine eyedrops. Acta Ophthalmol Scand Suppl. 2000;78(232):65-6.

11. Magacho L, Lima FE, Costa ML, Fayad FA, Guimaraes NL, Avila MP. Ibopamine provocative test and glaucoma: consideration of factors that may influence the examination. Curr Eye Res. 2004;28(3):189-93.

12. Lima, FE, Guimarães, NLD, Santos LM, Costa, LP, Ávila, MP. Ibopamina tópica na propedêutica do glaucoma. Rev Bras Oftalmol. 2002;61(2):109-13.

13. Brogliatti B, Boles Carenini A, Bogetto C, Vadala G, Grignolo FM, Boles Carenini B. Ibopamine test in healthy and glaucomatous eyes: tonometric and pupillographic study. Acta Ophthalmol Scand Suppl. 2000;(232):13-4.

14. De Gregorio F, Pecori Giraldi J, Pannarale L, Saccucci S, Virno M. Ibopamine in glaucoma diagnostics: a new pharmacological provocative test. Int Ophthalmol. 1996-97;20(1-3):151-5.

15. Barabino A, Galbariggi G, Pizzorni C, Lotti G. Comparative effects of longterm therapy with captopril and ibopamine in chronic congestive heart failure in old patients. Cardiology. 1991;78(3):243-56.

16. Dohmen HJ, Dunselman PH, Poole-Wilson PA. Comparison of captopril and ibopamine in mild to moderate heart failure. Heart. 1997;78(3):285-90.

17. Itoh H. Clinical pharmacology of ibopamine. Am J Med. 1991;90(5B):36S-42S.

18. Anderson DR, Patella VM. Automated static perimetry. 2th ed. St Louis: Mosby; 1999.

19. Quigley HA. Number of people with glaucoma worldwide. Br J Ophthalmol. 1996;80(5):389-93.

20. Lee, P. Economic Concerns in glaucoma management in the 21 st Century. J Glaucoma. 1993;2(2):148-51.

21. De Gregorio F, Pecori-Giraldi J, De Stefano C, Virno M. Correlation between ocular hypertension induced by ibopamine and perimetric defect in primary open-angle glaucoma. Eur J Ophthalmol. 1997;7(2):152-5.

22. Pivetti-Pezzi P, Da Dalt S, La Cava M, Pinca M, De Gregorio F, Virno M. Ibopamine treatment in chronic hypotony secondary to long-lasting uveitis. A case report. Eur J Ophthalmol. 2000;10(4):332-4. 